\title{
Effectiveness of tricks for cognitive management of children (TAMESHK) on behavioral dimensions of executive functions in children at risk for ADHD symptoms
}

\author{
Mahdis Maghsudloo ${ }^{1}$, ahid Nejati $^{2}$, Jalil Fathabadi ${ }^{3}$
}

1-Ph.D student, Shahid Beheshti University, faculty of psychology and education, Tehran, Iran. ORCID: 00000002-5232-5064

2- $\mathrm{PhD}$ of neuropsychology Associated professor, Shahid Beheshti University, faculty of psychology and education, Tehran, Iran. ORCID: 0000-0003-0419-5207Ｅ-mail: nejati@sbu.ac.ir

3- PhD of educational psychology, Associated professor, Shahid Beheshti University, faculty of psychology and education, Tehran, Iran. ORCID: 0000-0002-5667-857X

\section{Abstract}

Introduction: executive functions have dificts in attention deficit- hyperactivity disorder (ADHD) children.

Aim: The aim of this study is to evaluate effects of TAMESHK on executive functions of children with ADHD symptoms.

Method: This is an experimental study. Society includes 4-7 years old children with ADHD symptoms in Tehran in 2015-16 and among them 30 children randomly were selected. Instruments were ADHD symptom checklist and behavioral rating inventory of executive function. Repeated measure analysis of variance was used to analyze data.

Results: Results showed that the TAMESHK training was effective in improving executive functions $(\mathrm{P}=0.05)$ and reducing ADD symptoms $(\mathrm{P}=0.001)$ and effectiveness was permanent in 2 month follow-up.

Conclusion: TAMESHK training could be used as an effective way in decreasing cognitive deficits in children at risk for ADHD symptoms.

Keywords: executive functions, children, attention deficit hyperactivity disorder

How to cite this article : Maghsudloo M, Nejati V, Fathabadi J. Effectiveness of tricks for cognitive management of children (TAMESHK) on behavioral dimensions of executive functions in children at risk for ADHD symptoms. Shenakht Journal of Psychology and Psychiatry. 2018; 5 (4): 14-28 .URL : http://shenakht.muk.ac.ir/article-1-515-fa.pdf

Copyright $\odot 2018$ the Author (s). Published by Kurdistan University of Medical Sciences. This is an open access article distributed under the terms of the Creative Commons Attribution-Non Commercial License 4.0 (CCBY-NC), where it is permissible to download, share, remix, transform, and buildup the work provided it is properly cited. The work cannot be used commercially without permission from the journal. 


\title{
اثربخشى بسته ترفندهاى مديريت شناختى كودكان (تمشك) بر ابعاد رفتارى

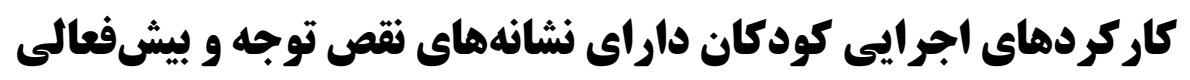

\author{
مهليس مقصودلو'، وحيد نجاتى '، جليل فتح آبادى \\ I. دانشجوى دكترى روانشناسى، دانشگاه شهيد بهشتى، دانشكده روانشناسى و علوم تربيتى، تهر ان، ايران.

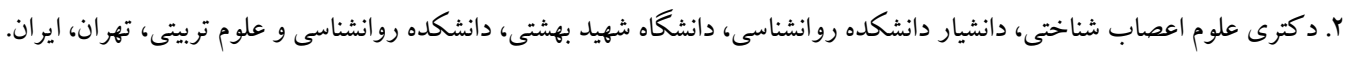 \\ nejati@sbu.ac.ir : ايميل \\ r. د كترى روانشناسى تربيتى، دانشيار دانشكده روانشناسى، دانشكاه شهيد بهشتى، دانشكده روانشناسى و علوم تربيتى، تهران، ايران.

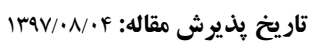

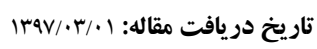

مقلمهل: كار كردهاى اجر ايى در كود كان مبتلا به اختلال نقص توجه و بيشفعالى (ADHD) نقص دارد. هدف: هدف از اين بثوهش بررسى اثر بسته آموزشى تمشكك بر كاركردهاى اجرايى كود كان داراى نشانههاى ADHD است. روش: روش يزوهش حاضر، آزمايشى است. جامعه آمارى متشكل از كليه كود كان F-V سال با علائم ADHD در شهر تهران در سال وه-هها1 بود كه از بين آنها ·r نفر تصادفى انتخاب شدند. ابزار يثوهش برسشنامه اختلال نقص توجه و بيشفعالى و يرسشنامه رفتارى كاركردهاى اجر ايى بود. دادهها با استفاده از تحليل واريانس اندازه گيرى مكرر تحليل شدند. يافتها: يافتها نشان داد بسته آموزشى تمشك بر بهبود كاركردهاى اجرايى (ه= (P) و كاهش نشانهاى نقص توجه كود كان تأثير معنادارى دارد و بهبودها تا يِيخيرى دوماهه يايدار مانده است. نتيجه كيرى: بسته آموزشى تمشك را مىتوان بهعنوان شيوهاى كار آمد براى كاهش نقايص شناختى كود كان داراى نشانه ADHD كليدوازهها: كار كردهاى اجرايى، كود كان، نقص توجه و بيش فعالى 



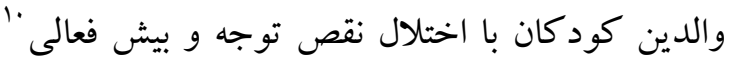

مقدمله

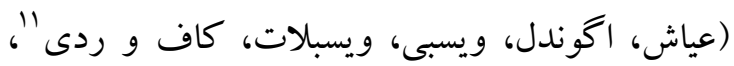

اختلال نقص توجه و بيش فعالى، يكك اختلال عصبى تحولى است كه با r دسته نشانه برتحركى و كم

در يزوهشها و فرا تحليلها بر مداخلاتى كه تاكنون با هاب

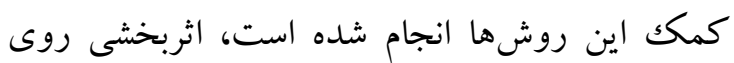

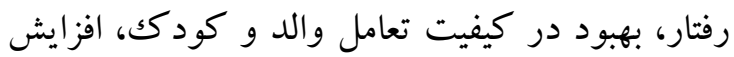
دستور يذيرى و كاهش در نشانهاى اختلال را نشان

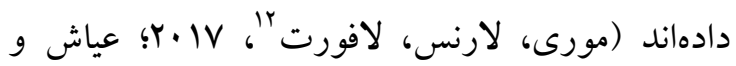

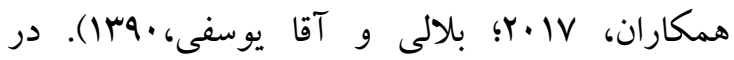
مطالعهاى بر كودكان ايرانى 9 تا fl سال نيز نشان دادهشده است كه رفتار درمانى و آموزش والدين تأثير زيادى بر كنترل رفتارهاى كود كان داراى نقص توجه و بيشفعالى داشته است (رقيبى، فولادى و بخشانى،

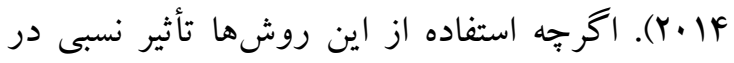
شكلدهى به رفتار كودكك دارد اما توجه به اين نكته آنه ضرورت دارد كه قسمت مهمى از نقصهايى كه در اختلال نقص توجه و بيشفعالى مشاهده مىشود، نقصهاى شناختى بخصوص نقص در كاركردهاى

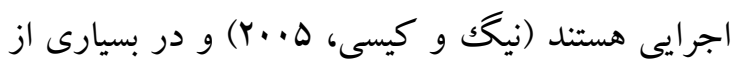
موارد آموزش رفتارى والدين بر مشكلات عصب شناختى زيربنايى اثر كذار نبوده است (اوانز، اون و ورئ

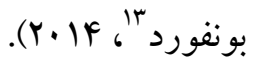

كار كردهاى اجرايى از جند مهارت شناختى سطح بالا و به هم بيوسته تشكيل شده است كه باعث مىشود

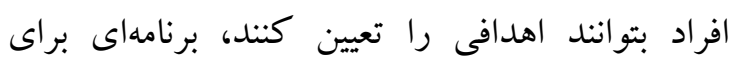
رسيدن به آن تنظيم كنند و بدانند كه جِكونه اين برنامه

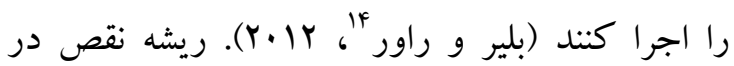
كاركردهاى اجرايى افراد مبتلا به اختلال نقص توجه و بيشفعالى در سالهاى قبل از مدرسه است يس بـ بـ توجهى مشخص مىشود. شيوع اين اختلال در كود كان

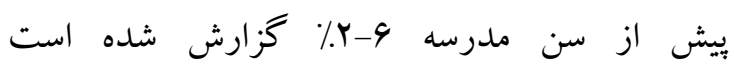

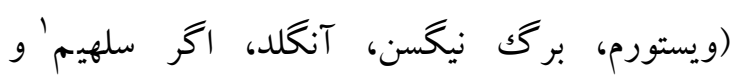

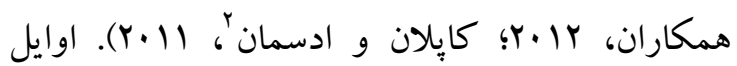
كود كى دوره مهمى براى مشاهده تأثيرات والدگرى بر

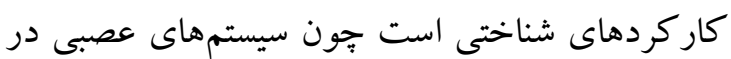
اوايل كودكى بيشترين انعطافيذيرى را دارند

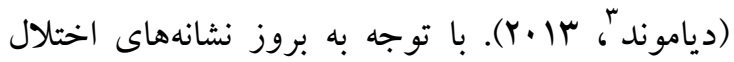

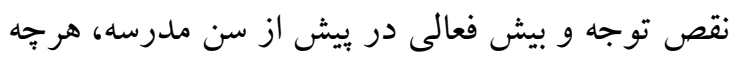

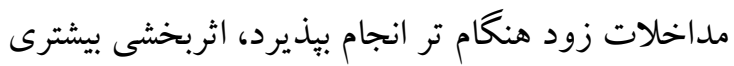

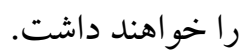
از جمله آموزشهايى است كه تاكنون در رابطه با والدين كود كان داراى اختلال نقص توجه و بيش فعالى بخصوص كود كان قبل از سن مدرسه صورت بذيرفته،

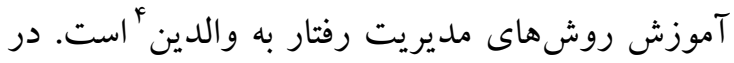
اين روشها بيشتر استفاده از اصول مديريت رفتار به مدريه

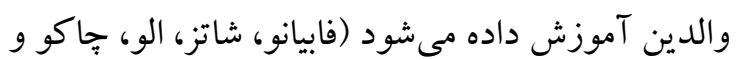

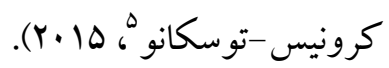

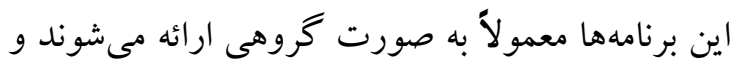

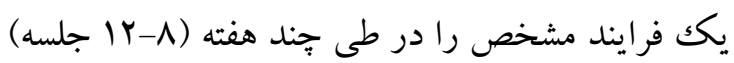

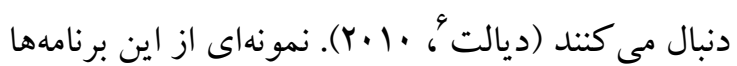
سالهاى باورنكردنى (وبستر استراتون، رينالدى و ريدّاء

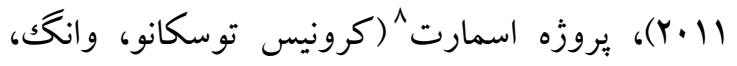

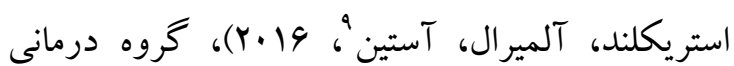

\footnotetext{
${ }^{1}$ Wichstrom, Berg,Nielsen, Angold, Egger \& solheim

${ }^{2}$ Kaplan \& Adesman

${ }^{3}$ Diamond

${ }^{4}$ Behavior parent training

${ }^{5}$ Fabiano, Schatz, Aloe ,Chacko \& Chronis-Tuscano

${ }^{6}$ Deault

${ }^{7}$ Webster Stratton, Rinaldi \&Reid

${ }^{8}$ Sequential Multiple Assessment Randomized Trial (SMART)

${ }^{9}$ Chronis-Tuscano, Wang, Strickland, Almirall \& Stein
} 
راهبردهاى جبرانى براى بهبود عملكردهاى حافظهاى

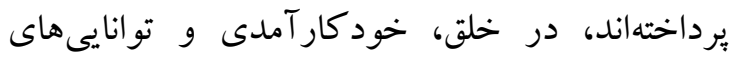
عملكردى خود گزارشى افراد داراى آسيبهاى شناختى خفيف "ههبود ديده شده است. اين راهبردهاى جبرانى در حيطه حافظه شامل استفاده از تقويمها،

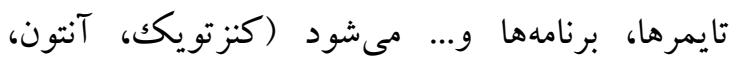
كرين، مفمشادى و كشكى اين ئزوهش طراحى و اجراى بسته آموزشى براى

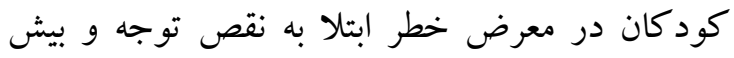

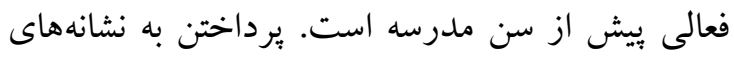

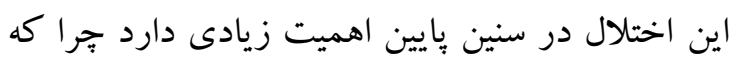
با كاهش نشانهها در سنين قبل از مدرسه مىتوان از

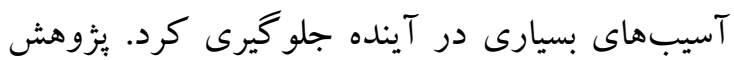
حاضر بررسى اين فرضيه را مدنظر دارد كه با آموزش

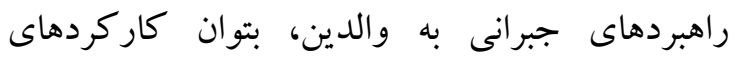

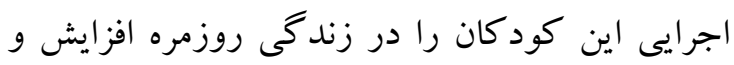
نشانهاى نقص توجه و بيش فعالى را در آنان كاهش رون رون

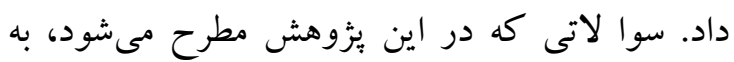

$$
\text { شرح زير است: }
$$

ا-توانبخشى جبرانى بر بهبود كاركردهاى اجرايى

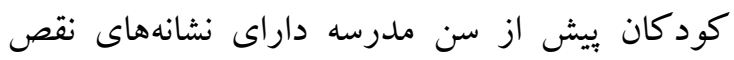
توجه و بيش فعالى تأثير مثبت دارد. Y- توانبخشى جبرانى بر بهبود نشانههاى نقص توجه و و بيش فعالى كودكان بيش از سن مدرسه داراى نشانهاى نقص توجه و بيش فعالى تأثير مثبت دارد.

روش اين يُزوهش از نوع طرحهاى آزمايشى است كه در

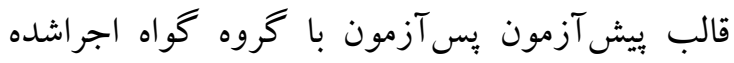

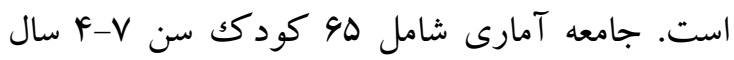

${ }^{5}$ Mild cognitive impairment

${ }^{6}$ Konsztowicz, Anton, Crane, Moafmashhadi \& Koski,
شناسايى و مداخله زود هنگام در مديريت اين اختلال

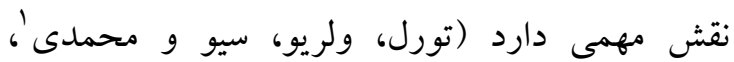

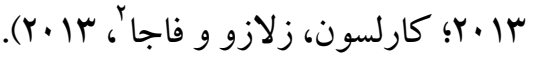
با استفاده از روشهاى توانبخشى شناختى، مداخلات

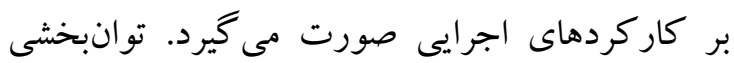
شناختى از دو راه مىتواند به بهبود اين كاركردها كمك كند. ا-با استفاده از روشهاى ترميمى كه در آن كار كرد شناختى آسيبديده مستقيماً مورد مداخله قرار مى گيرد. ب- روشهاى جبرانى كه در آن از راهبردها و مهارت هاى جايخزين براى جبران نقص در

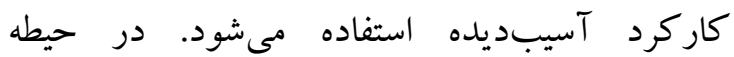
توانبخشى به راهبردهاى جبرانى بيشتر در قالب تغيير در رفتار توجه شده است ولى در واقع تغييرات نورولوزيكك هم ايجاد مىشوند و رفتار جديد باعث بازسازى يا بازسازماندهى جرخه عصدي إجى داراى آسيب

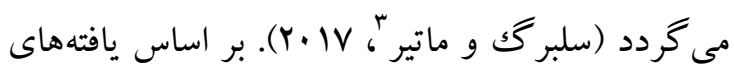
محقق، تنها يكك مطالعه در حوزه استفاده از راهبردهاى جبرانى براى افراد با اختلال نقص توجه و بيش فعالى

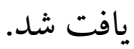
كنلا، بوادز، دوب، ايج و ليبرنز ${ }^{\varphi}$

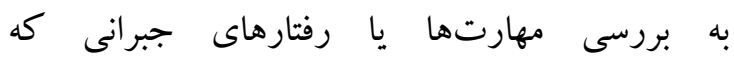
بزرگك سالان دار اى اختلال نقص توجه و بيش فعالى قبل

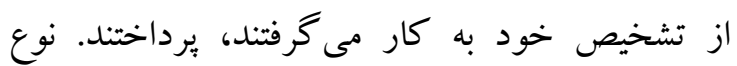
روشها يا مهارتهاى جبرانى كه آنها قبل از تشخيص استفاده مى كردند، مورد ارزيابى قرار كرفت مهارئ. آنها براى افزايش سطح توجه از كاهش دادن محركك و براى افزايش مهارت سازماندهى از ابزارهاى

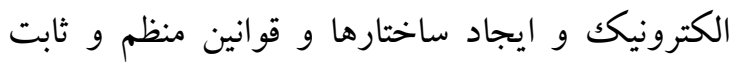
استفاده مى كردند. در مطالعهاى كه به استفاده از

\footnotetext{
${ }^{1}$ Thorell,Veleiro, Siu, \& Mohammadi

${ }^{2}$ Carlson, Zelazo \& Faja,

${ }^{3}$ Sohlberg \& Mateer

${ }^{4}$ Canela, Buadze, Dube, Eich \& Liebrenz
} 
داشته باشند. بر همين مبنا، والدين كودكان گروه

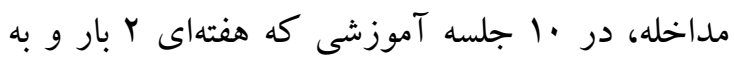

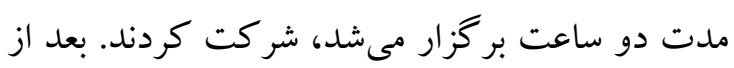

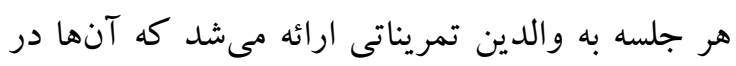

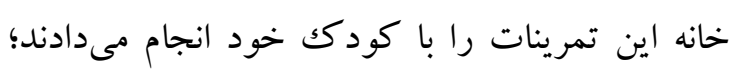
سبس براى جلسه بعد گزارشى از روند كار خود ارائه مى كردند. بعد از اتمام مداخله، ارزيابىهاى پِ بس آزمون

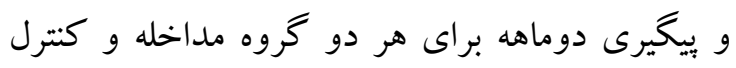

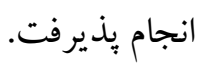

ابزار برسشنامه مشخصات فردى: اين :برسشنامه شامل دو قسمت الف و ب مىشد. در قسمت الف مادران اطلاعات مرتبط با خود و در قسمت ب اطلاعات مرتبط با فرزند خود را تكميل مى كردند. اين برسشنامه بهمنظور جمع آورى اطلاعات توصيفى در رابطه با مرتيا متغيرهاى سن، سطح تحصيلات، نوع مسكن، اشتغال، ورود كودكك به محيطهاى آموزشى، وجود اختلالات بزشكى يا روانيزشكى ديخر مورداستفاده قرار كرفته وردي

يرسشنامه اختلال نقص توجه و بيشفعالى': ؛رسشنامه

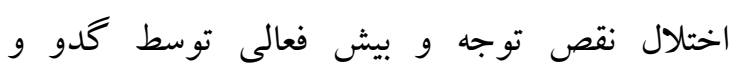

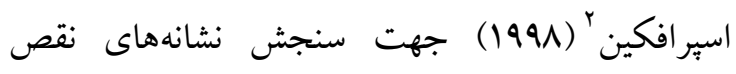
توجه و بيش فعالى در كود كان بين سن 1 |-r سال تهيه شده است. اين يرسشنامه دو فرم والد و معلم دارد و شامل •ه سؤال مىشود. زير مقياسهاى آن عبارتاند از: بىتوجهى (سؤالهاى 9-1)، بيشفعالى (سؤالهاى ||- ·1) و نقص توجه و بيش فعالى (سؤالهاى 11-1).

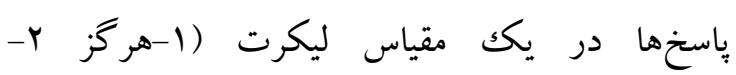
بعضىاوقات ب- اغلب F- هميشه) قرار مى گيرند.

${ }^{1}$ ADHD symptom checklist-4 (ADHD-SC4)
داراى نشانهاى نقص توجه و بيش فعالى مراجعه كننده

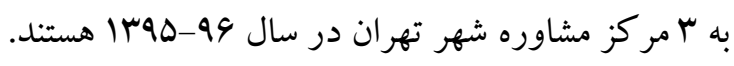

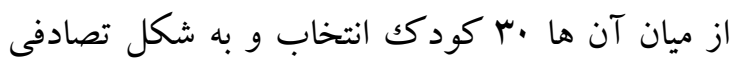
در دو كروه مداخله (ه) (هودكك) و كنترل كودكك) جاى گرفتند. انتخابها يا رعايت ملاككهاى مروه ورود گروه نمونه انجام بذيرفت. معيار ورود كود كان به كروه نمونه وجود حداقل •هـ\% از نشانهاى اختلال نقص توجه و بيش فعالى بر اساس معيارهاى ذكر شده

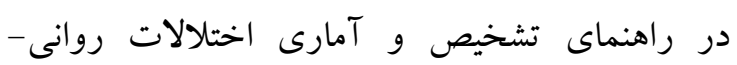

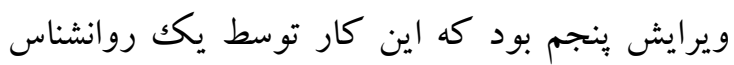

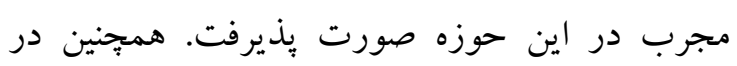

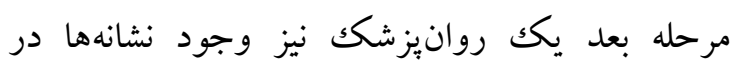

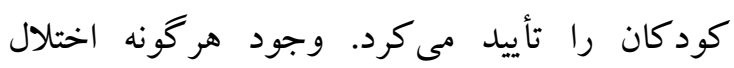
يزشكى (مانند صرع و...) و اختلال روانيز شيكى مانع از ورود كود كان به گروه نمونه مى شد. بعلاوه معيار ديخر

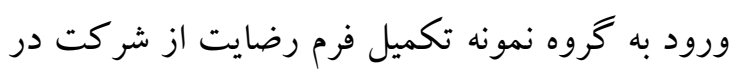
تحقيق بود. ييش از شروع هر نوع مداخله، در مورد

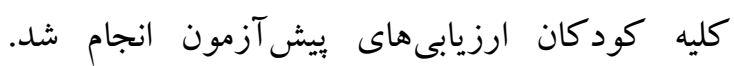

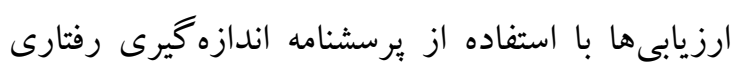

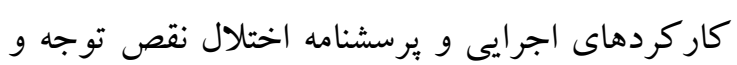

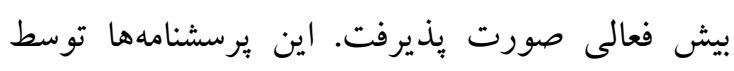

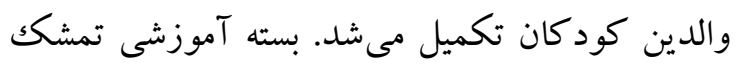
براى كمكك به رفع نقصهاى شناختى كودكان تهيه

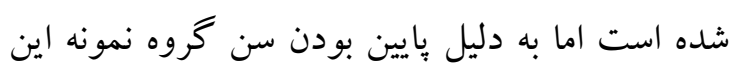

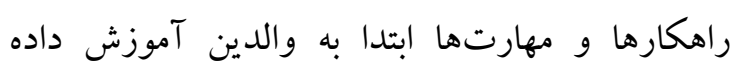
مىشود و بعد والدين كودكك خود را در زنداكى مهاري روزمره هدايت مى كنند كه جّكونه از آنها استفاده كند. در بسته توانبخشى جبرانى تمشك ورهى والدين

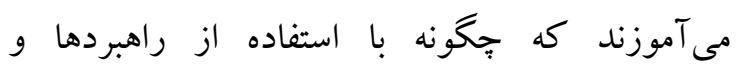
مهارتهاى مختلف به كود كان خود كمكك كنند تا بر بر به

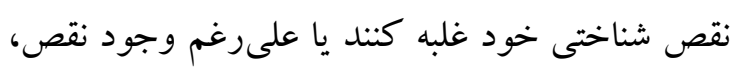
عملكرد قابل قبولى در فعاليتهاى زندگى نئى روزمره 
بسته آموزشى توفنلدهاى مديريت شناختى كودكان (تمشك): مقصودلو و نجاتى (4ها) به طراحى بسته آموزشى ترفندهاى مديريت شناختى كودكان

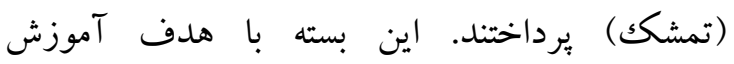
روشهاى توانبخشى شناختى جبرانى تهيه شده است. تمشكك با استفاده از اصول توانبخشى جبرانى به تهنى والدين يايههاى عصبشناختى آسيبديده در اين اختلال، مشكلات رفتارى ناشى از اين آسيبها و راههاى بهبود عملكرد كاركردهاى آسيبديده را آموزش مىدهد. از بين كاركردهاى اجرايى 9 كاركردى كه اين دوره سنى قابليت بررسى داشتند انتخاب و برنامه مداخلاتى بر مبناى اين كاركردها تهيه

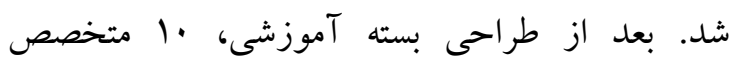

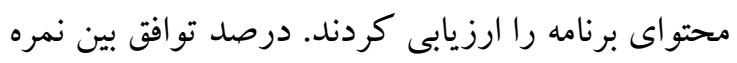

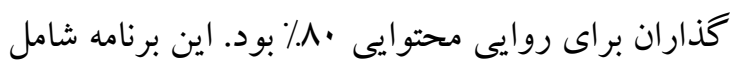

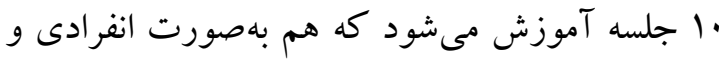

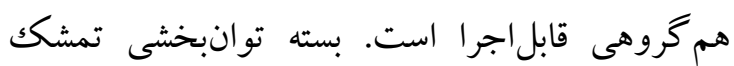
موضوعات زير را يوشش مىدهد: آموزش روانى شناختى، مديريت رفتار، انواع كاركردهاى اجرايى،

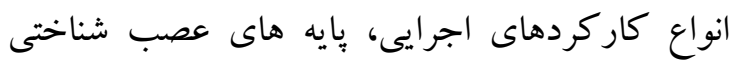
رفتار در كودكان مبتلا به اختلال نقص توجه و بيش فعالى، راهبردهاى مديريت نقصهاى شناختى كود كان. هر جلسه با مكالمه آزاد در رابطه با مشكلاتى كه رهئ والدين در حين اجراى راهبردها مو اجه مىشدند، شروع مىشد. سيس موضوع اصلى جلسه مطرح مىشد و

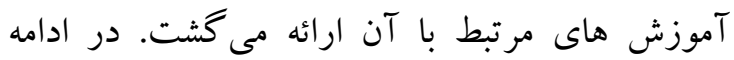
والدين در مورد راهكارها و نحوه ارائه آنها بارش هوري مغزى و بازى نقش انجام مىدادند. در پِيان هر جلسه والدين تشويق مىشدند كه اين راهبردها و مهارتها را با كودكان خود انجام دهند و از آنها خواسته مىشد كه بر كه تكاليف را براى جلسه بعد تكميل كنند. براى

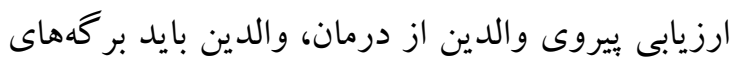

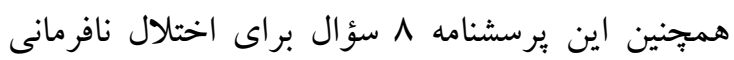
مقابلهاى و · أؤال براى نشانهاى اختلال سلو كك و تعارض با همسالان دارد. عوارض جانبى داروها مثل خلق، نشانهاى رفتارى و بدنى را نيز در لأ سؤال مىسنجد. اعتبار و روايى قابل قبولى براى اين برسشنامه

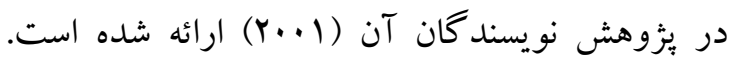
اعتبار درونى اين آزمون با استفاده از آلفاى كرونباخ هم براى مقياس مشكلات توجه و همجينين بيش فعالى إنى (r= •) و روايى محتوايى آزمون در توافق بين نمره

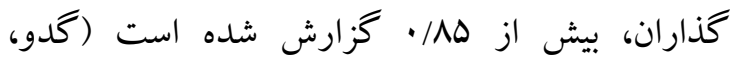

$$
\text { اسبر افكين و نولان'، (Y... (Y). }
$$

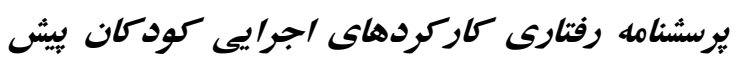

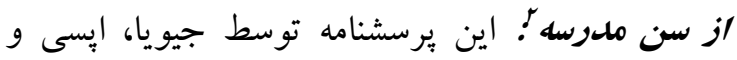

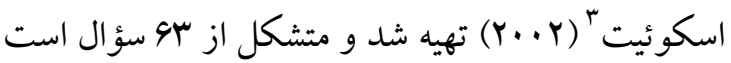
كه تظاهرات رفتارى مختلف كاركردهاى اجرايى را در بافت موقعيتهاى روزمره زندگى بر پايه نظر والدين

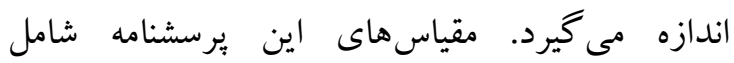
بازدارى، تغيير، كنترل هيجانى، حافظه فعال، برنامهريزى

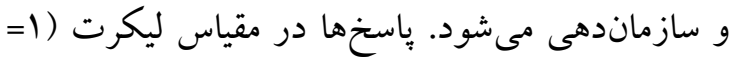

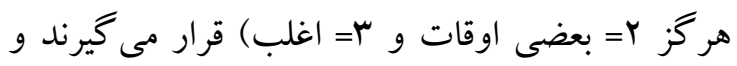
تكميل اين برسشنامه •1-10ا دقيقه زمان مىبرد. اعتبار

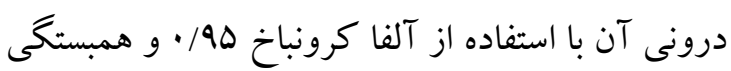

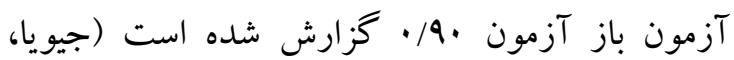

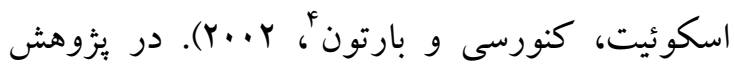

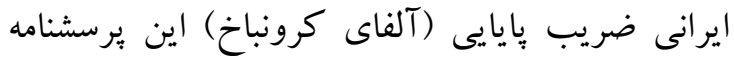

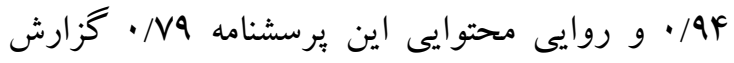

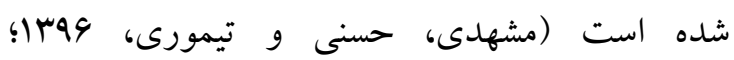

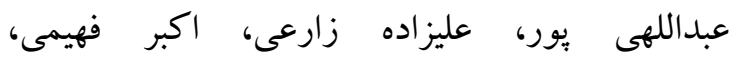

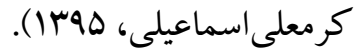

\footnotetext{
${ }^{1}$ Gadow, Sprafkin \& Nolan

${ }^{2}$ Behavioral rating inventory of executive functionpreschool(BRIEF-P)

${ }^{3}$ Gioia

${ }^{4}$ Isquith, Kenworthy \& barton
} 
با ميزان كاربردى بودن و انعطاف هر راهبرد يا مهارت در مورد كود كان آنها صحبت مىشد. والدين نظرات خود را در مورد مؤثر بودن يا مشكل بودن استفاده از هر راهبرد بيان مى كردند.
ثبت روزانه را تكميل مى كردند. آنها بايد تعداد دفعاتى كه هر راهبرد را استفاده كردهاند، ثبت روردي مى كردند. در هر جلسه بر كهاى تكاليف تكميلشده، از والدين دريافت مى شد. بعلاوه در هر جلسه در رابطه

\section{جدول ا: خلاصه جلسات بسته آموزشى تمشك}

\begin{tabular}{|c|c|}
\hline موضوع & 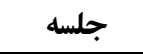 \\
\hline \multirow{2}{*}{\multicolumn{2}{|c|}{ درمان، دوز روانى به والدين در رابطه با اختلال نقص توجه و بيشفعالى كه شامل نشانها، شيوع، تفاوتهاى جنسيتى، عواقب ناشى از عدم }} \\
\hline & \\
\hline آموزش اصول اوليه مديريت رفتار & 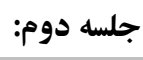 \\
\hline تبيين مفهوم كار كردهاى اجر ايى و تفاوت آن با هوش & جلسه سوم: \\
\hline
\end{tabular}

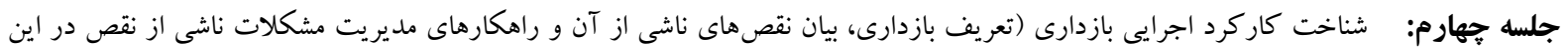

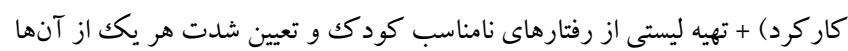

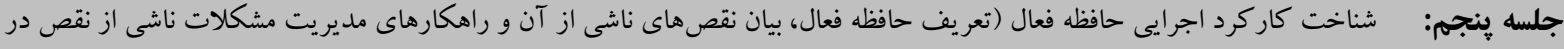

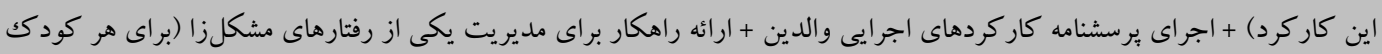

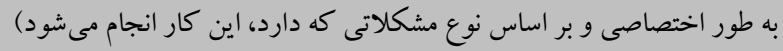

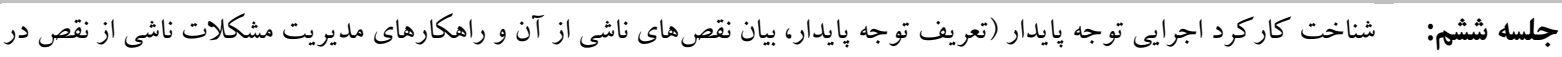

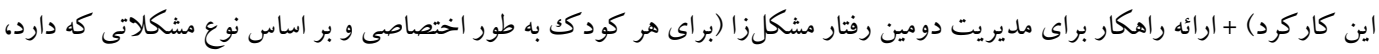

اين كار انجام مىشود)

جلسه هفتم: شناخت كاركرد اجر ايى انعطافيذيرى (تعريف انعطافيذيرى إنى بيان نقصهاى ناشى از آن و راهكارهاى مديريت مشكلات ناشى از نقص در اين كاركرد)

شناخت كاركردهاى اجرايى برنامهريزى و مديريت زمان (تعريف برنامهريزى و مديريت زمان، بيان نقصهاى ناشى از آنها آنها و جلسه هشتم:

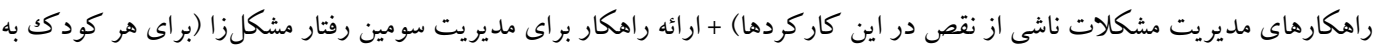

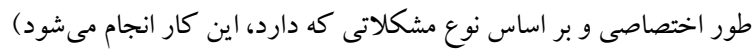

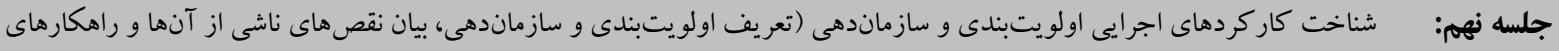

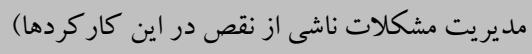

سن باردارى مادران YV سالكى بوده و 19 مادر كودكى خود را به مهد مىفرستادند و 19 نفر ديخر در خانه نكهدارى مى كردند. ميانگين سنى كود كان ها هال بود.

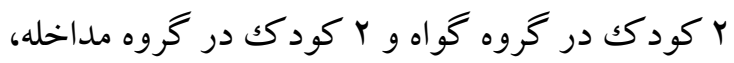
داروى مرتبط با اختلال نقص توجه و بيشفعالى مصرف مى كردند. كودكان تشخيص هيج اختلال

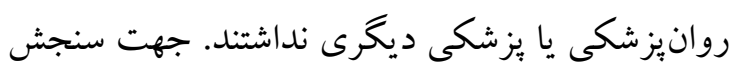

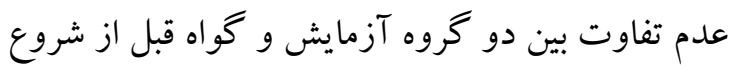

يافتهها دادههاى اين بيزوهش در ابتدا با استفاده از تحليل واريانس اندازهيرى مكرر و سبس تحليل كوواريانس جند متغيرى تحليل شدند. در ابتدا به بررسى ويزگگىهاى جمعيت شناختى مادران و و كودكان يرداخته مىشود. ميانگين سنى مادران در گرووه نمونه

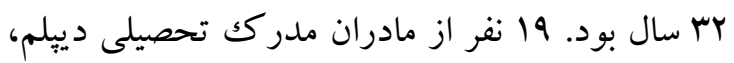
• ا نفر كارشناسى و \مانفر ارشد و دكترا داشتند. از بين مادران 9 نفر شاغل و بr نفر خانهدار بودند. ميانگين 


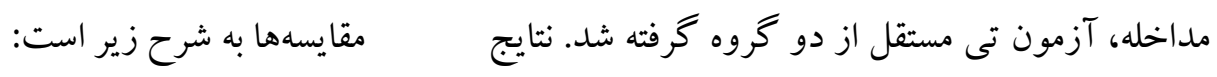

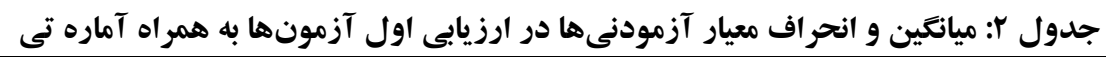

\begin{tabular}{|c|c|c|c|c|c|}
\hline \multirow[t]{2}{*}{ آماره تى } & \multicolumn{2}{|c|}{ 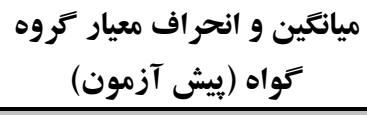 } & \multicolumn{2}{|c|}{ 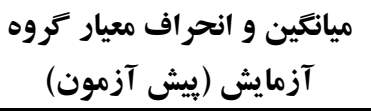 } & \multirow[t]{2}{*}{ متغير ها } \\
\hline & انحراف معيار & ميانگين & انحر اف معيار & ميانغين & \\
\hline $1 / 94$ & $r / \uparrow \Lambda$ & $r r / A r$ & $F / \Delta 9$ & rq/1T & بازدارى \\
\hline . & $r / 9$. & $19 / 41$ & $\Delta / r$. & $1 V / 49$ & تغيير توجه \\
\hline $1 / 19$ & $r / 19$ & $19 / 79$ & $\Delta / r \Delta$ & $r Y / \cdot 4$ & تنظيم هيجانى \\
\hline$\cdot / \Delta V$ & $9 / 49$ & $r Y / \cdot \cdot$ & $\Delta / M$ & ITr/ar & حافظه \\
\hline$\cdot / 41$ & $F / N$ & $19 / 19$ & $r / \mu r$ & $r \cdot 149$ & برنامهريزى \\
\hline $1 / r Y$ & $19,9 \mathrm{~V}$ & $|r| / r q$ & $19 / 11$ & $1 r q / .9$ & نمره كل كاركردهاى اجرايى \\
\hline 1/09 & $8 / 19$ & $19 / 41$ & r/a9 & $r Y / . \cdot$ & نقص توجه \\
\hline $1 / \cdot 4$ & $9 / 4 \Lambda$ & $r F / F I$ & $\Delta / .1$ & rq/Dr & بيش فعالى \\
\hline $1 / 4 \Delta$ & $1 . / r Y$ & $\mathrm{Kr} / \mathrm{Ar}$ & $V / 9$. & YN/Dr & نقص توجه و بيش فعالى \\
\hline
\end{tabular}

نمرات دو گرووه يس از مداخله و در مرحله يِگيرى در جدول زير ارائه شده است.
همان طور كه در جدول فوق مشاهده مىشود دو گرووه از لحاظ عملكرد در آزمونها بيش از ارائه مداخله

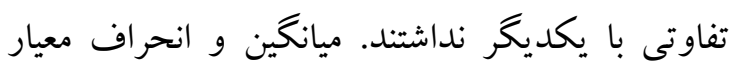

جدول "ا: ميانكين و انحراف معيار نمرات دو كروه يس از مداخله و در مرحله يبيكيرى

\begin{tabular}{|c|c|c|c|c|c|c|c|c|}
\hline \multicolumn{2}{|c|}{ 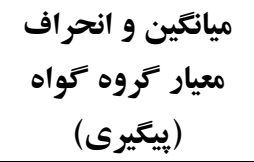 } & \multicolumn{2}{|c|}{ 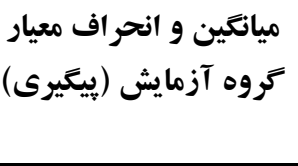 } & \multicolumn{2}{|c|}{ مريانكين و انحراف معيار } & \multicolumn{2}{|c|}{ 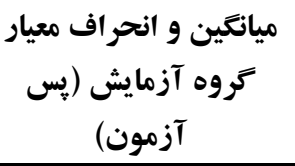 } & \multirow[t]{3}{*}{ متغيرها } \\
\hline انحراف & ميانكين & انحراف & ميانگين & انحراف & ميانكين & انحراف & ميانكين & \\
\hline معيار & & معيار & & معيار & & معيار & & \\
\hline$r / \pi 1$ & $\Gamma r / \Delta \Lambda$ & $9 / \pi 1$ & rV/AT & r/VA & $r F / \Delta r$ & $r / 9 V$ & $r V / r$. & بازدارى \\
\hline$r / . r$ & $1 N / \cdot \Delta$ & $F / 1$. & $19 / 49$ & $F / r$. & IV/AY & $r / r \Lambda$ & $\mid f / 1 r$ & تغيير توجه \\
\hline$r / 91$ & $19 / .0$ & $F / T V$ & $19 / 14$ & $r / r r$ & $r .1 .0$ & $r / l r$ & $\mid V / F$. & تنظيم هيجانى \\
\hline$\Delta / v \wedge$ & $\mu K / T \Delta$ & v & rV/ar & 9191 & TY/AY & $9 / 41$ & $r q / 4$. & حافظه \\
\hline$r / \pi r$ & $19 / v$. & $F / I r$ & IV/99 & r/AD & $r \cdot / 11$ & $4 / .9$ & $\mid V / T r$ & برنامهريزى \\
\hline $19 / 11$ & IYT/QF & $r V / q$. & $1.8 / \wedge 9$ & F/99 & ITS/TS & r. & $1.0 / 49$ & نمره كل كاركردهاى \\
\hline$F / \Lambda \Delta$ & $r 1 / r q$ & $r / T r$ & $19 / \pi r$ & $r / T$ & $r \cdot / \% \Delta$ & $r / \notin q$ & $I V / r$. & نقص توجه \\
\hline$F / N$. & $Y F / I$ & $V / F q$ & $Y Y / .9$ & $\Delta / 9 F$ & raIVG & G/VD & re/F. & بيشفعالى \\
\hline$\Lambda / \pi r$ & $F 1 / F \Delta$ & $9 / \Delta 9$ & ץ & $9 / \cdot 1$ & $F / 11$ & $\Lambda / \Delta Q$ & $41 / 9$. & نقص توجه و فيش \\
\hline
\end{tabular}


نتايج مفروضههاى تحليل واريانس در جدول زير ارائهده است.
جهت بررسى معنادار بودن تفاوت ميانگينهاى گروه

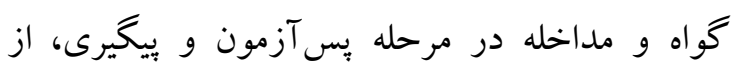
تحليل واريانس اندازهگيرىهاى مكرر استفاده شد.

\begin{tabular}{|c|c|c|c|c|c|}
\hline \multicolumn{2}{|c|}{ كرويت موخلى } & \multicolumn{2}{|c|}{ 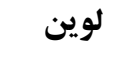 } & \multirow{2}{*}{ 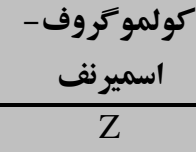 } & \multirow[t]{2}{*}{ متغير } \\
\hline $\mathrm{X}^{2}$ & W & $\mathrm{F}$ & & & \\
\hline$r / F \Delta$ & $\cdot / v^{\prime}$ & $\cdot / \Lambda$ & & .1 & بازدارى \\
\hline $\mathrm{V} / \boldsymbol{V}$ & $\cdot / \Delta V$ & F/aF & * & $\cdot /$ lf & تغيير توجه \\
\hline$V / \Delta r *$ & $\cdot / 09$ & $F / M^{4}$ & * &.$/ 1 F$ & تنظيم هيجانى \\
\hline $9 / \wedge 9 \%$ *** & .149 & $\cdot / 4$ & & . Ir & حافظه \\
\hline$r / \Delta \Delta$ & $\cdot / v$ & $\cdot / M$ & & $\cdot /$. & برناملريزى \\
\hline $1 r / r q *$ & . & $1 / \pi$ & &.$/ .9$ & نمره كل كار كردهاى اجرايى \\
\hline 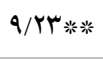 & $\cdot / 49$ & $r / 14$ & & $\cdot / \cdot 1$ & نقص توجه \\
\hline$F / T r$ & $\cdot \mathrm{NI}$ & $1 / 16$ & & $\cdot 1$ & بيشفالى \\
\hline $8 / .9$ & $.19 \mathrm{~V}$ & $1 / \pi c$ & & $\cdot / \mathrm{IV}$ & نقص توجه و بيش فعالى \\
\hline
\end{tabular}

برقرارى ماتريس كوواريانس متغيرهاى وابسته در اين متغير دارد؛ اما معنى دار بودن كرويت موخلى درو درو متغيرهاى بازدارى، برنامه ريزى، بيش فعالى و نقص توجه و بيش فعالى نشان مى دهد فرض همخوانى بـ بردي ماتريس كوواريانس خطاى مربوط به متغير وابسته برقرار نيست. لذا از نتايج مربوط به معنادارى گرين هوس گيسر استفاده شد.
جدول F نشان مىدهد بيش فرض طبيعى بودن توزيع

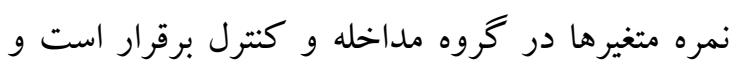
همسانى در واريانس هاى نمره هاى كود كان به جز در متغيرهاى تغيير توجه و تنظيم هيجانى مشاهده مىشود.

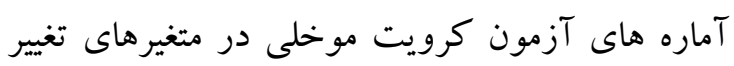
توجه، تنظيم هيجانى، حافظه، نمره كل كاركردهاى اجرايى و نقص توجه غير معنى دار است كه دلالت بر هره

جدول ه: نتايج تحليل اندازهيرى مكرر در مورد تأثير توانبخشى جبرانى بر كار كردهاى اجرايى و نشانههاى نقص توجه و بيش فعالى

\begin{tabular}{|c|c|c|c|c|c|}
\hline \multirow{2}{*}{ ضريب اتا } & \multirow{2}{*}{$\begin{array}{c}\text { F } \\
r q / V^{\circ} \text { 光米 }\end{array}$} & \multirow{2}{*}{ مجانكين } & \multirow{2}{*}{ مجذورو مجزورات } & \multicolumn{2}{|c|}{ اثرات درون كروهى } \\
\hline & & & & كرينهاوس-گيسر & بازدارى \\
\hline$\cdot / \cdot \wedge$ & $1 / r 9$ & $1 Y / V 9$ & $19 / 4$. & فرض كرويت & تغيير توجه \\
\hline$\cdot / r V$ & D/r & $\wedge \vee / \cdot \wedge$ & $\wedge ৭ / \cdot \wedge$ & فرض كرويت & تنظيم هيجانى \\
\hline 洪 & $F / Y G_{*}$ & $V \wedge / 9 \Lambda$ & $V N / 9 \Lambda$ & فرض كرويت & حافظه \\
\hline$\cdot / r_{1}$ & $r / N r_{*}$ & $r Y / \cdot r$ & $r V / F r$ & گر ينهاوس -گيسر & برنامهريزى \\
\hline . & $\mathrm{V} / \mathrm{M}$ 粪米 & YIAY/YA & $r \mid \Lambda Y / Y \Lambda$ & فرض كرويت & كار كردهاى اجرايى \\
\hline
\end{tabular}




\begin{tabular}{|c|c|c|c|c|c|}
\hline$\cdot / Y \Lambda$ & $\Delta / 99$ 米米 & $\Delta r /$. & VF/AY & فرض كرويت & نقص توجه \\
\hline$\cdot / 4$. & 9/9. 光粠 & $11 r / \cdot V$ & $I V G / Y A$ & گ خرينهاوس-گيسر & بيش فعالى \\
\hline
\end{tabular}

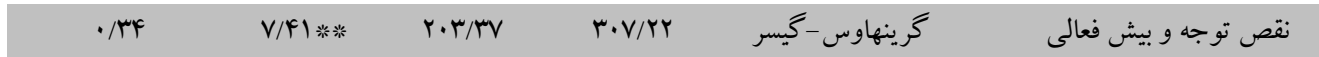

${ }^{*} \mathrm{P}<\cdot 1.0^{* * *} \mathrm{P}<\cdot / .1$

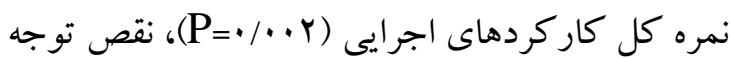

(P=•/.・q)

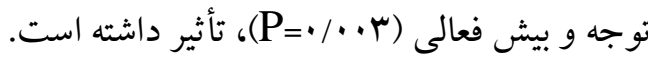

نتايج جدول ه نشان مىدهد كه توانبخشى جبرانى بر

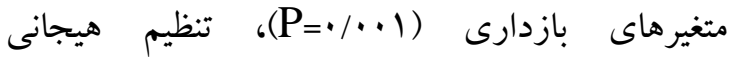

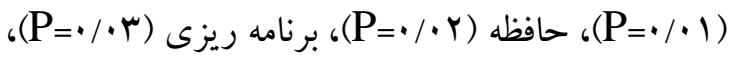

جدول و: نتايج آزمون تعقيبى بنفرونى براى تعيين اثر مداخله بر كاركردهاى اجر ايى و نشانهاى

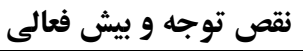

\begin{tabular}{|c|c|c|c|c|c|c|}
\hline \multicolumn{2}{|c|}{ يس آزمون - يِيَيرى } & \multicolumn{2}{|c|}{ يبش آزمون - ييكيرى } & \multicolumn{2}{|c|}{ بيش آزمون - يِس آزمون } & \multirow[t]{2}{*}{ متغير } \\
\hline انحراف معيار & اختلاف ميانگين & انحراف معيار & اختلاف ميانكين & انحراف معيار & اختلاف ميانگين & \\
\hline$\cdot 109$ & 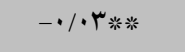 & .199 & 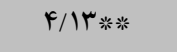 & $\cdot / A Y$ & $ץ / 19$ 米絭 & بازدارى \\
\hline$\cdot \mid 91$ & $-\cdot \pi$ & •/^ & $\cdot / \wedge$ & $\cdot / 4 \Lambda$ & $1 / 1$. & تغيير توجه \\
\hline$\cdot / v q$ & $1 / 1$. & $\cdot / 91$ & $r / 4 r$ & $\cdot / 4 \Delta$ & 1/Tr\% & تنظيم هيجانى \\
\hline.$/ 91$ &.$/ . r$ & $\cdot|A|$ & $r / . \cdot$ & $\cdot / \mu F$ & 1/99* & حافظه \\
\hline. $\mid 91$ & -.1 .4 & .191 & $1 / \pi r$ & $\cdot / 4$ & $1 / 4 \cdot \%$ & برنامهريزى \\
\hline$\Gamma / \Gamma 1$ &.$/ 9$ & $r / \Lambda)$ & $1 \cdot / \wedge 9 *$ & $1 / \Phi_{0}$ & १/৭९* & كار كردهاى اجرايى \\
\hline. $\mid 9 V$ & -.1 .4 & . & 1/9. & $\cdot / \pi q$ & $1 / 99_{*}$ & نقص توجه \\
\hline$\cdot / 9 \Delta$ & $r / . r_{*}$ & . ND & $r / 9 \cdot \%$ & $\cdot / \Delta 9$ & $-\cdot / 14$ & بيش فعالى \\
\hline $1 / T \Delta$ & r/99 & $1 / \pi 9$ & $\varphi / \Delta \cdot * *$ & $\cdot / v 9$ & I/AT & نقص توجه و بيش فعالى \\
\hline
\end{tabular}

${ }^{*} \mathrm{P}<\cdot 1 \cdot 0^{* *} \mathrm{P}<\cdot / \cdot 1$

\section{بحث و نتيجه كيرى}

اين مطالعه با هدف بررسى تأثير بسته آموزشى تمشك ديرى

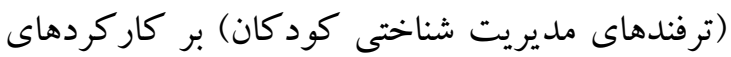

اجرايى كود كان داراى نشانهاى نقص توجه و بيش فعالى انجام يذيرفت. نتايج مطالعه حاكى از اثربخشى اين روش بر كاركردهاى بازدارى، تنظيم هيجانى، تغيير توجه، حافظه و نشانهاى نقص توجه كود كان است. يافتهاى به دست آمده از اين يُزوهش با نتيجه

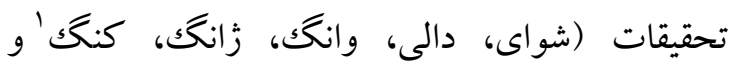

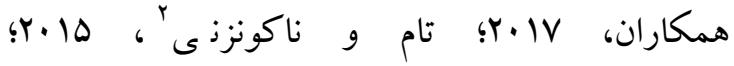

نتايج جدول 4 نشان مىدهد كه تفاوت ميانگين

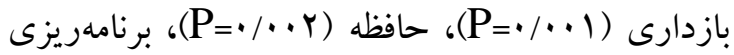

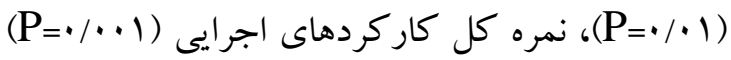

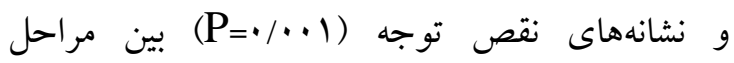
يِيش آزمون و يس آزمون معنى دار است. همجِنين اين

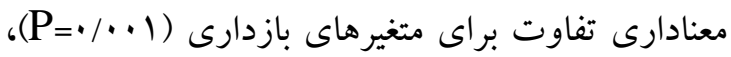

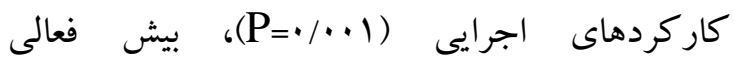

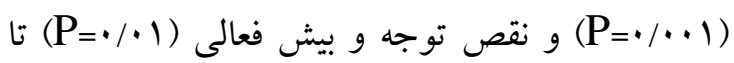
مرحله بيخيرى ادامه داشته است. در ابعاد بازدارى

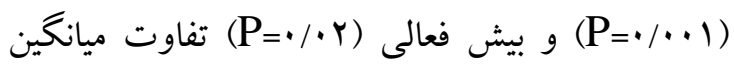
بس آزمون و بيگيرى نيز معنادارى نشان مىدهد.

${ }^{1}$ Shuai, Daley, Wang, Zhang \& Kong 
بازدارى، انعطافيذيرى شناختى و افزايش كنترل توجه، توجه بايدار، حافظه فعال و برنامهريزى دارد

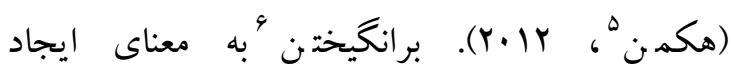

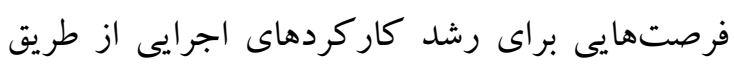

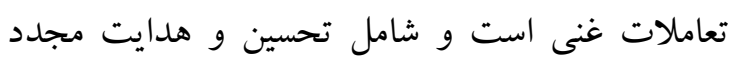

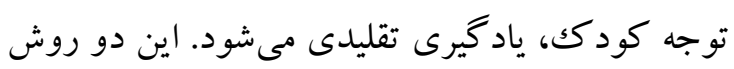

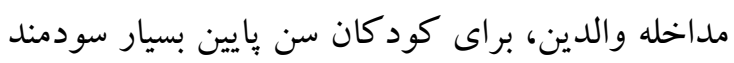

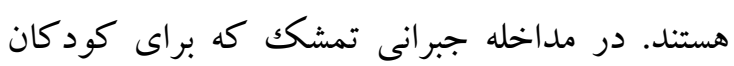

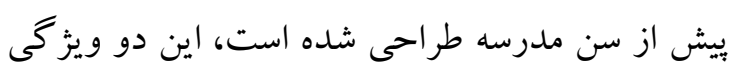
اثر بخش والدين لحاظ شده بود. برنامه جبرانى توسط آس

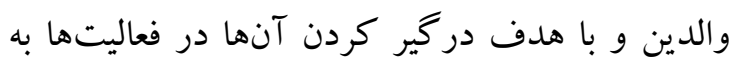

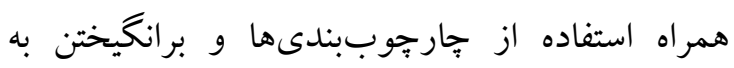

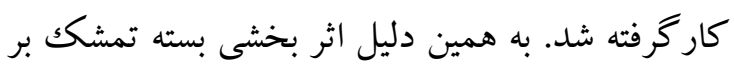

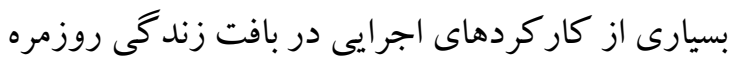

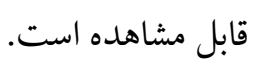
از آنجا كه گُروه نمونه برّوهش كنونى، كود كان قبل از سن مدرسه هستند، اهميت نقش والدين مضاعف

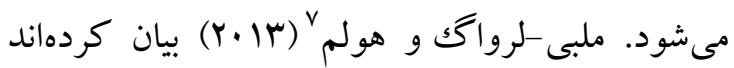

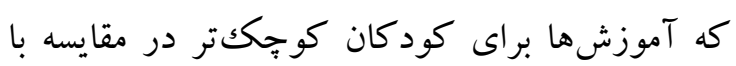

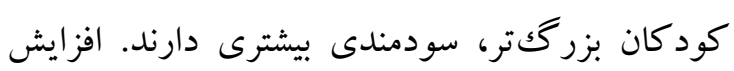
كاركردهاى اجرايى در سنين قبل از مدرسه افزايش بـ برد

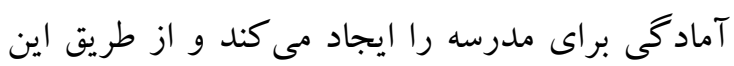

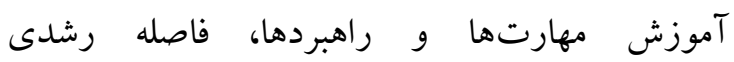
كار كردهاى اجرايى كود كان داراى اختلال نقص توجه

و بيش فعالى با همسالان نرمال خود كاهش مى يابد.

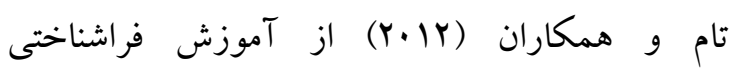
كاركردهاى اجرايى به عنوان روشى براى بهبود

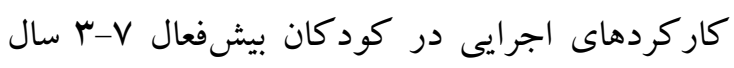
استفاده كردند. در اين روش كود كان و والدين به درديه صورت مجزا در ^ جلسه ا ساعته كه هفتهاى يككبار

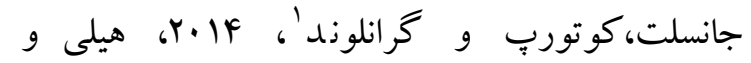
هاليرين'، ها ·r؟؛ دانش، حكيمى، شمشيرى و سليمى

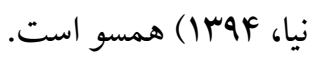

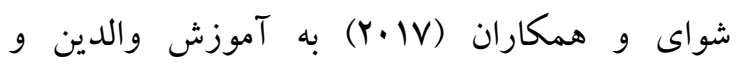
كودكان داراى اختلال نقص توجه و بيش فعالى با هوال هدف طراحى برنامهاى كه مهارت ها و راهبردهاى لازم

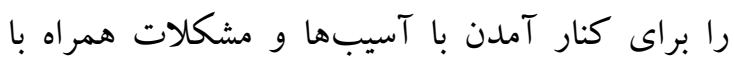
اختلال نقص توجه و بيش فعالى به كودكان و و خانوادههاى آنها آموزش دهد. بازدارى، حافظه فعال، برنامهريزى، سازماندهى، مديريت زمان و تنظيم هيجان برداختند. بعد از مداخله،

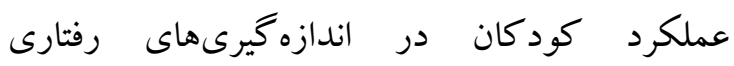
كاركردهاى اجرايى در زندگى روزمره، افزايش بيدا كرد. در تبيين اثربخشى اين دسته از آموزشها مهى توردان بيان كرد كه وقتى مداخلات توسط والدين در محيط

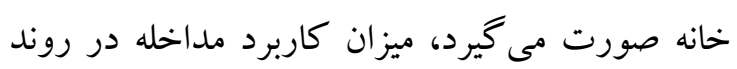

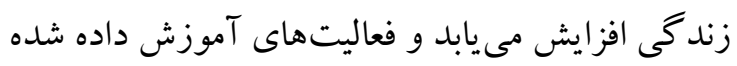
به بافت زندكى روزمره تعميم بيدا مى كند كه همين

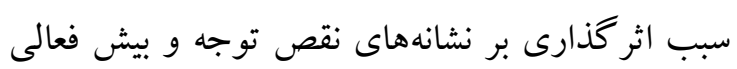
هم مىشود (تام و ناكونزنى، ها +r؛ هيلى و هالِيرين،

$(Y \cdot 10$

زمانى كه والدين مبتنى بر اصول جهارجوب بندى

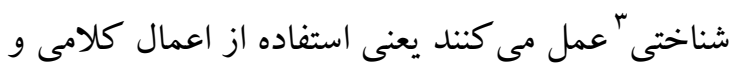
غير كلامى براى هدايت كودكى و نغه داشتن او در تكاليفى كه برايش سخت است، كاركردهاى اجرايى

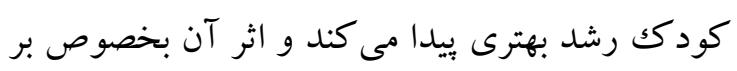
حافظه فعال و توانايى تغيير توجه نشان داده شده است

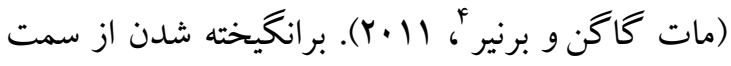
والدين نيز تأثير بسزايى بر رشد كاركردهاى اجرايى بردي

\footnotetext{
${ }^{1}$ Janslett, Kottorp, Granlund

${ }^{2}$ Healy, Halperin

${ }^{3}$ Scaffolding

${ }^{4}$ Matte-Gagne, Bernier
} 
به كار بستن مهارت r- استفاده از مهارتهاى منفعلانه

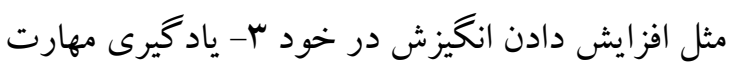

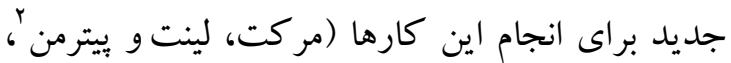

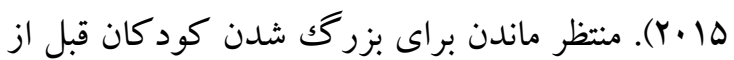
سن مدرسه و ايجاد اين آمادگكى در كود كان به معناى برى از دست دادن فرصتهاى طلايى در رشد مغز است كه در اين دوره سنى بيشترين انعطافيذيرى را براى يذيرش تغييرات دارد. بر همين اساس با ايجاد كمى ليق تغيير در اصول ذكر شده در بالا، بسته توانبخشى جبرانى تمشكك براى كودكان بيش از سن مدرسه

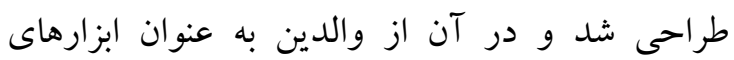
كمكى براى عمل به اصول ذكر شده در بالا استفاده

مطالعه فرا تحليل كراس، فرين، برنويس، بوتلار، دالى

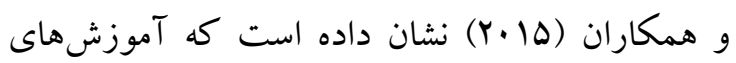
شناختى بر نشانهاى نقص توجه كودكان داراى نقص توجه و بيش فعالى اثر كذار بوده است. بعلاوه آنها تأكيد كردهاند كه اكر فرايندهاى نورو سايكولوزيكك متنوعترى هدف مداخله قرار بـيرند، اثرات انتقالى مداخله روى كاركردهاى شناختى و تغيير در نشانهاى اين اختلال بيشتر خواهد شد. از جمله جنبهاى قابل توجه اين بزوهش اين است كه طيف كستردهاى از كار كردهاى اجرايى را هدف قرار مىدهد. بسيارى از مداخلات در كذشته بر روى آموزش جزء خاصى از كاركردهاى اجرايى متمر كز بودهاند (تام، هاكز، آمز،

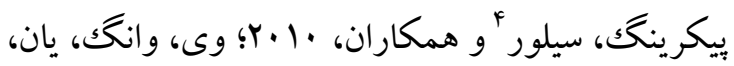

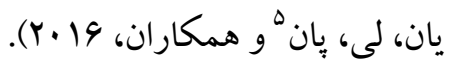
از جمله محدوديتهاى بثزوهش حاضر خروه نمونه

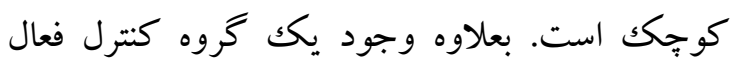

\footnotetext{
${ }^{2}$ Merkt, Reinelt, Petermann

${ }^{3}$ Cortese, Ferrin, Brandeis, Buitelaar, Daley

${ }^{4}$ Tamm, Hughes, Ames, Pickering \& Silver

${ }^{5}$ Wei, Wang, Yan, Li, Pan \& Cui
}

تشكيل مىشد، مورد مداخله قرار گرفتند. نتايج اين مطالعه حاكى از بهبود در توانايى تغيير توجه، تنظيم هيجانى و نشانهاى نقص توجه بود. به صورت كلى

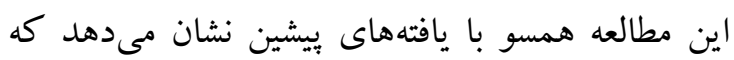

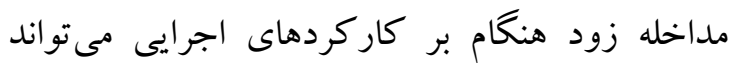
اثرات مثبتى بر كاركردهاى آنها در زندگى روزمره و بعلاوه نشانهاى نقص توجه و بيش فعالى داشته باشد. در تبيين اثر بخشى مداخلات روى كودكان مى توان از

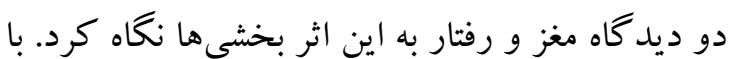
در نظر گرفتن تغييرات در مغز مىتوان اين گونه بيان كرد كه ظرفيت كاركردهاى اجرايى و سطوح فعاليت مغزى همراه با آن ثابت نيستند و بهوسيله تمرين و و آموزش مى تواند تغيير ييدا كنند (كلينكبر كى، •l+Y). مغز در دوره سنى بيش از مدرسه از آمادگى بالايى براى تغيير برخوردار است. مغز درحال رشد در باسخ به محر كك هاى محيطى مختلف مثل استرس يا تجربيات دوران كودكى تغيير بيدا مى كند. تمرين مكرر يك مهارت منجر به ايجاد تغييرات بلند مدت در ساختار نورونى مىشود ماند تغيير در حجم ماده سفيد يا خاكسترى مغز، بخصوص اكر در طى بازه زمانى طولانى تر و با تكرار بيشترى آن تمرين انجام شده باشد.

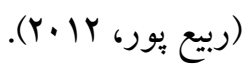

در تبيين رفتارى اثربخشى مداخلات جبرانى روى كود كان به ويزگ گیىهاى جبران روانشناختى مى توان اشاره نمود. جبران روانشناختى به معنى عدم تطابق مهارت با انتظارات محيطى است. راهبردهاى جبر انى به بهبود عملكرد فرد كمكك مى كنند حتى علىرغم اينكه نقصهاى ناشى از اختلال باقىمانده باشند (كرملى،

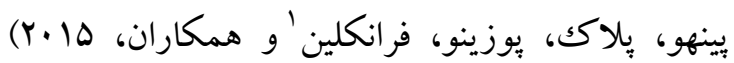
براى اين منظور فرد از سهراه براى جبران روانشناختى استفاده مى كند ا- زمان و تلاش بيشتر براى يادگيرى

${ }^{1}$ Goremly, Pinho, Pollack,pozino, Franklin 
problems of children. Joumal of Applied Psychology,4(20): 59. [In Persian].

Blair, C., \& Raver, C. C. (2012). Child development in the context of adversity: experiential canalization of brain and behavior. American Psychologist, 67(4): 309.

Canela, C., Buadze, A., Dube, A., Eich, D., \& Liebrenz, M. (2017). Skills and compensation strategies in adult ADHD-A qualitative study. PLoS One, 12(9): e0184964.

Carlson, S. M., Zelazo, P. D., \& Faja, S. (2013). The OxfordHandbook of Developmental Psychology, Vol. 1: Body and Mind.

Cortese, S., Ferrin, M., Brandeis, D., Buitelaar, J., Daley, D., Dittmann, R. W. \&Zuddas, A. (2015). Cognitive training for attentiondeficithyperactivity disorder: meta-analysis of clinical and neuropsychological outcomes from randomized controlled trials. Joumal of the American Academy of Child \& Adolescent Psychiatry, 54(3): 164-174.

Danesh, E., Hakimi, z., Shamshiri, M., Saliminia, N. (2015). Effectiveness of behavior management skills training for mothers to reduce the symptoms attention deficit/ hyperactivity disorder in their children. Joumal of Applied Psychology, 9 (34): 25-41[In Persian].

Diamond, A. (2013). Executive functions. Annual Review of Psychology, 64, 135-168. Doi: 10.1146/annurev-psych-113011-143750

Evans, S. W., Owens, J. S., \& Bunford, N. (2014). Evidence-based psychosocial treatments for children and adolescents with attentiondeficithyperactivity disorder. Journal of Clinical Child and Adolescent Psychology, 43(4): 527551.

Fabiano, G. A., Schatz, N. K., Aloe, A. M., Chacko, A., \& Chronis- Tuscano, A. (2015). A systematic review of meta-analyses of psychosocial treatment for attention deficithyperactivity disorder. Clinical Child and Family Psychology Review, 18(1): 77-97.

Fay-Stammbach, T., Hawes, D. J., \& Meredith, P. (2014). Parenting influences on executive function in early childhood: A review. Child Development Perspectives, 8(4): 258-264.

Gadow, K. D., Sprafkin, J., \& Nolan, E. E. (2001). DSM-IV symptoms in community and clinic preschool children. Joumal of the American

$$
\begin{aligned}
& \text { مىتواند اثر شركت كردن فعال والدين در درمان يا } \\
& \text { انتظارات آنها از درمان را خنثى كند. محدوديت } \\
& \text { ديخر، عدم وجود سيستم نظارتى براى سنجش ميزان }
\end{aligned}
$$

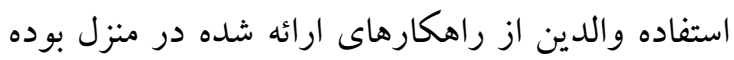

$$
\begin{aligned}
& \text { است. بيشنهاد مىشود در ئزوهشهاى آينده از } \\
& \text { ارزيابهاى نآشنا به روند درمان (روش دو سركور) } \\
& \text { براى ارزيابىهاى ييش از مداخله و پِّ از مداخله }
\end{aligned}
$$

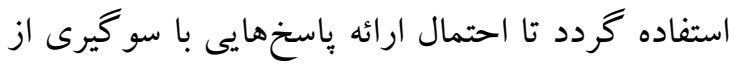

$$
\begin{aligned}
& \text { سمت والدين كاهش بيدا كند. } \\
& \text { نتيجه يُوهش كنونى نشان مىدهد كه مداخله در سنين }
\end{aligned}
$$

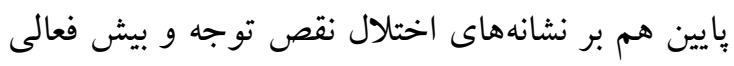

$$
\begin{aligned}
& \text { و هم بر نقايص موجود در كاركردهاى اجرايى اين } \\
& \text { كود كان مىتواند اثر گذار باشد. اين كاهش در نقايص }
\end{aligned}
$$

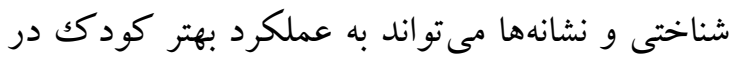

$$
\begin{aligned}
& \text { سالهاى آينده كمكك فراوانى كند. }
\end{aligned}
$$

$$
\begin{aligned}
& \text { سياسگزارى }
\end{aligned}
$$

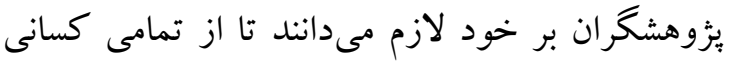

$$
\begin{aligned}
& \text { كه در انجام يُزوهش به بُزوهشخران يارى رساندند }
\end{aligned}
$$

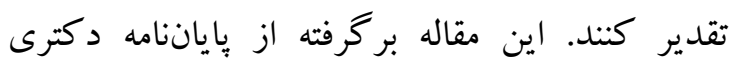

$$
\begin{aligned}
& \text { روانشناسى است و از مسئولين دانشگاه شهيد بهشتى } \\
& \text { جهت حمايت در انجام اين ئوهش تشكر مى شود. }
\end{aligned}
$$

\section{References}

Abdollahipour, F., Alizadeh Zarei, M., Akbar Fahimi, M., Karamali Esmaeili, S. (2016). Study of Face and Content Validity of the Persian Version of Behavior Rating Inventory of Executive Function, Preschool Version. Jrehab, 17(1):12-19. [In Persian].

Ayyash, H., Ogundele, M.O., Wisbey, R., Weisblatt, E., Cuff, L., \& Reddy, V. (2017). The outcome of an $\mathrm{ADHD}$ parenting group training programme (APEG) in the Peterborough Neurodevelopmental Service (NDS).

Balali, R., Aghayousefi, A. (2012). Effects of parental training program on the reduction of behavioral 
Gioia, G. A., Isquith, P. K., Kenworthy, L., \& Barton, R. M. (2002). Profiles of everyday executive function

in

acquired and developmental disorders. Child neuropsychology, 8(2): 121-137.

Gormley, M. J., Pinho, T., Pollack, B., Puzino, K. Franklin, M. K., Busch, C., ... \& Anastopoulos, A. D. (2018). Impact of study skills and parent education on first-year GPA among college students with and without ADHD: A moderated mediation model. Joumal of attention disorders, 22(4), 334-348.

Hackman, D. A. (2012).Socioeconomic status and the development ofexecutive function and stress reactivity: The specific roles of parentalnurturance and the home environmen( $\mathrm{PhD}$ dissertation). Depart-ment of Psychology, University of Pennsylvania, Philadelphia, PA.Available from ProQuest Dissertations \& Theses Global database

Healey, D. M., \& Halperin, J. M. (2015). Enhancing Neurobehavioral Gains with the Aid of Games and Exercise (ENGAGE): Initial open trial of a novel early intervention fostering the development of preschoolers' self-regulation. Child Neuropsychology, 21(4): 465-480.

Kaplan, A., \& Adesman, A. (2011). Clinical diagnosis and management of attention deficit hyperactivity disorder in preschool children. Current opinion in pediatrics, 23(6): 684-692.

Klingberg, T. (2010). Training and plasticity of working memory. Trends in cognitive sciences, 14(7): 317-324.

Konsztowicz, S., Anton, J., Crane, J., Moafmashhadi, P., \& Koski, L. (2013). A pilot study of training and compensation interventions for mild cognitive impairment. Dementia and geriatric cognitive disorders extra, 3(1): 192-201.

Mashahdi, A., Hasani, J., Teymouri, S. (2017). Psychometric Properties of Preschool Behavior Rating Inventory of Executive Function: Parent Form. Joumal of Clinical Psychology, 9(33): 7583. [In Persian].

Matte-Gagne, C., \& Bemier, A. (2011). Prospective relations betweenmatemal autonomy support and child executive functioning: Inves-tigating the mediating role of child language ability.Joumal ofExperimental Child Psychology,110, 611-625.
Academy of Child \& Adolescent Psychiatry, 40(12): 1383-1392.

Melby-Lervåg, M., \& Hulme, C. (2013). Is working memory training effective? A meta-analytic review. Developmental psychology, 49(2), 270.

Merkt, J., Reinelt, T., \& Petermann, F. (2015). A framework of psychological compensation in attention deficit hyperactivity disorder. Frontiers in psychology, 6, 1580.

Murray, D. W., Lawrence, J. R., \& LaForett, D. R. (2017). The Incredible Years $\AA$ Programs for ADHD in Young Children: A Critical Review of the Evidence. Joumal of Emotional and Behavioral Disorders, 1063426617717740.

Nigg, J. T. \& Casey, B. J. (2005). An integrative theory of attention-deficit/ hyperactivity disorder based on the cognitive and affective neurosciences. Development and Psychopathology, 17(3): 785-806.

Rabipour, S. (2012). Computerized Attention Training for Childhood Behavior Disorders: A Non-pharmaceutical Treatment Approach (Doctoral dissertation, McGill University Libraries).

Raghibi, M., Fouladi, S., \& Bakhshani, N. M. (2014). Parent training and behavior therapy on behaviors of children with attention deficithyperactivity disorder. Health Scope, 3(2). [n Persian].

Shuai, L., Daley, D., Wang, Y.F., Zhang, J. S., Kong, Y. T., Tan, X., \& Ji, N. (2017). Executive Function Training for Children with Attention Deficit Hyperactivity Disorder. Chinese Medical Joumal, 130(5), 549.

Sohlberg, M. M., \& Mateer, C. A. (2017). Cognitive rehabilitation: An integrative neuropsychological approach. Guilford Publications.

Tamm, L., Hughes, C., Ames, L., Pickering, J., Silver, C. H., Stavinoha, P., \& Bolanos, S. G. (2010). Attention training for school-aged children with ADHD: Results of an open trial. Joumal of Attention Disorders, 14(1): 86-94.

Tamm L, Nakonezny PA, Hughes CW (2012) an open trial of a metacognitive executive function training for young children with ADHD. J Atten Disord, 18(6): 551-559

Tamm, L., \& Nakonezny, P. A. (2015). Metacognitive executive function training for young children with ADHD: a proof-of-concept 
study. ADHD Attention Deficit and Hyperactivity Disorders, 7(3): 183-190.

Thorell, L. B., Veleiro, A., Siu, A. F., \& Mohammadi, H. (2013). Examining the relation between ratings of executive functioning and academic achievement: Findings from a cross-cultural study. Child Neuropsychology, 19(6): 630-638.

Webster-Stratton, C., Rinaldi, J., \& Reid, J. M. (2011). Long-term outcomes of Incredible Years Parenting Program: Predictors of adolescent adjustment. Child and Adolescent Mental Health, 16(1):38-46.

Wei, Y. Y., Wang, J. J., Yan, C., Li, Z Q., Pan, X., Cui, Y., ... \& Tang, Y. X. (2016). Correlation between brain activation changes and cognitive improvement following cognitive remediation therapy in schizophrenia: An activation likelihood estimation meta-analysis. Chinese medical joumal, 129(5): 578.

Wichstrom, L., Berg-Nielsen, T. S., Angold, A., Egger, H. L., Solheim, E., \& Sveen, T. H. (2012). Prevalence of psychiatric disorders in preschoolers. Joumal of Child Psychology and Psychiatry, 53(6): 695-705. 